\title{
The Philosophical Values of the Buginese-makassarese Women in the novel Pulau Based on the Adat Point of View: A Genetic Structural Review
}

\author{
Syarifuddin Tundreng ${ }^{1 *}$, E. Emzir², Ninuk Lustyantie ${ }^{2}$ \\ ${ }^{1}$ Universitas Sembilanbelas November, Indonesia \\ ${ }^{2}$ Universitas Negeri Jakarta, Indonesia
}

Corresponding Author: Syarifuddin Tundreng, E-mail: syarifuddintunreng@usn.ac.id

\section{ARTICLE INFO} \\ Article history \\ Received: March 13, 2018 \\ Accepted: May 10, 2018 \\ Published: June 30, 2018 \\ Volume: 9 Issue: 3 \\ Advance access: May 2018 \\ Conflicts of interest: None \\ Funding: None \\ Key words: \\ Gender Values, \\ Buginese-makassarese Female, \\ Customs, \\ Adat, \\ Novel Pulau, \\ Genetic Structures
}

\begin{abstract}
The purpose of this study is to obtain an in-depth understanding of the description of BugineseMakassarese women's values in the novel Pulau by Aspar Paturusi from a customary (adat) point of view completely and intact. This research, using a qualitative approach with content analysis method. Data were collected through a recurrent and profound reading of the novel. Subsequently, recording, coding, identification, and classification were made. The data were analyzed and interpreted through a deep understanding and abstraction of the society described in the novel. The research findings show that in the life of the society of the " $70 \mathrm{~s}$, the values of Buginese-Makassarese women in the novel Pulau by Aspar Paturusi covering the values of glory, loyalty, and tenacity value, adherence value, and family honor are highly preserved, nurtured, and upheld. These values are attached to Buginese-Makassarese women because they are able to understand and apply their roles and functions as identity, pride, and family honor.
\end{abstract}

\section{INTRODUCTION}

Ethnic of Buginese-Makassarese are the two majority tribes that inhabit South Sulawesi region. Both tribes are basically different ethnic groups, but culturally and daily activities are very difficult to find the difference. One example of the similarity of the Buginese and Makassarese people is in enacting women based on adat (customary) provisions. The Buginese and Makassarese customs view women as a symbol of family siri' and related to the concept of men. When women are humiliated, self-esteem is lost as Buginese-Makassarese people. How important the position of women in customary views, so that women are associated with a crown that needs to be guarded and protected. As a result, women should be closely monitored and their behavior not only overseen by parents but also by close and distant family members or even by members of the surrounding community, better referred to as tomasiri' (a person who is responsible for keeping the family siri') (Idrus, 2014).

In the presentation of the novel Pulau by Aspar Paturusi, there are some segments of the story about the role and function of Buginese-Makassarese women.
The depiction of the figure mother (amma) Aminah and Isa is a replica of the Buginese-Makassarese women in South Sulawesi. Buginese-Makassarese women have multi-talent in supporting husbands both in their work and in the effort to supplement their income. The condition is caused by the situation that requires the women in Tanjung Bira to consciously have to replace the role of husband to be the head of the household for a while until the husband comes home from the voyage. They work together to work for their needs and to keep their family alive. Therefore, Buginese-Makassarese women in addition to being known as gentle also have the character of courage. This courageous nature is needed in keeping the family from the distractions and threats that can come at any time. In the perspective of gender (women), Ery Iswari (2010: 144) presented the bold character of Makassarese women in South Sulawesi. The brave nature is based on research of folklore texts of the Buginese-Makassarese culture. She discovered the phenomenal women of extraordinary and great and courageous women.

The researcher's experience sees that there are significant differences between Buginese-Makassarese women in the 70s who are told in novels and the Buginese-Makas- 
sarese women today. Values that are owned and pinned on the Buginese-Makassarese women in the 70s are very much guarded and uphold. The values of glory, loyalty, and compliance are very much in line with the Buginese-Makassarese female character of the 70s. In addition, they deeply understand the role and function as women who are based on adat provisions and in accordance with the religious shari'a. The condition is contradictory with the Buginese-Makassarese women of today. Their role and function as Buginese-Makassarese women are slowly leaving behind. Values that are the basic values of the Buginese-Makassarese women pinned from the ancestors (to riolo) have been degraded. This is certainly a very alarming phenomenon.

The values of virtue that should be owned by the Buginese-Makassarese women are now degraded. Adat is a key concept in overcoming the changing role and function of Buginese-Makassarese women today. For that reason, adat needs to be understood and applied, because the Buginese-Makassarese people belief in adat that underlies all the ideas about their relationships, whether with their fellow human beings, with their social institutions, as well as with the natural surroundings, even the macrocosm. If we are able to discover or express its meaning in family life, economics, politics, government, and religion, then we can understand the view of their lives which is supplied by their adat.

In restoring the authenticity of Buginese-Makassarese women in accordance with adat, there needs to be a wise move we must do. Publicizing positive values in the form of novel research is one positive step that needs to be done. For that reason, the problem studied in this research is how is the position of Buginese-Makassarese woman in the novel Pulau by Aspar Paturusi based on customary (adat) point of view? Meanwhile, in answering the problems in research, the researchers used a genetic structural approach. This approach focuses on the social conditions of society, the relationship of literary works to society, and the author's worldview. As a collective consciousness, the worldview evolves as a result of the particular social and economic situation faced by the collective subjects who possess it. The worldview is the extracting of the ideas of a particular social group and is contrasted with the ideas of other social groups. (Goldmann, 1981: 111-112).

\section{THEORETICAL BASIS}

\section{The Concept of Adeq/Adat (Custom) of Buginese-Makassarese}

Adeq, Buginese language (panngaderreng) and Pangaddakkang, the Makassarese language (adat) which serves as a view of life that regulates the mindset and human behavior completely. Buginese-Makassarese society has a very strict social value about adat as a guideline in social relations that must be implemented. According to Mattulada, (2015: 416) adat is a form of culture which is in addition to understanding the system of norms and rules of custom and order, also contains elements that include all human life activities behave and organize life infrastructure in the form of materials and non -material. Meanwhile, La Tadamparek Puang ri Magalatung, Arung Matoa Wajo (1491-1521) described Panngaderrang/Pangadakkang as follows.

Naia riaseng e tellutoi: seuani, allalengeng malempuk, maduanna tomappala leng malempuk, to mallaleng malempuk, aga tennassarang puraonroe, pura laloe.... The so-called Panngaderrang is divided into three types: first, proper walking (rule of law) and straight. Secondly, the person who orders to live (the officer who orders the execution of the law) who is straight, and thirdly, the person who is ordered to obey the righteous will not be separated from the previously applied rule, which cannot be changed again (Hamid, Mattulada, Lopa, Abidin, \& Salpmbe, 2014: 36-37).

The philosophical concept of the ancestors personified the custom as a human being with a glorious position of the so-called person. The noble position is due to the functioning and the role of trust and morality in the fabric of relationships. A person behaves as human beings in relation to themselves (rialena), with their fellow beings (padanna ripancaji), with their ideals (risennurenna), and with God (ri DewataE) (Rahim, 1985: 143). Further, in Lontara' is expressed about the concept of ade'/ada' that: Iyya nanigesaraki adakbiasana buttaya temmatikami balloka, tanaiktonganbngami jukuka, sala tongi aseya. That is, if custom is damaged, then palm wine (tuak) stop dripping, fish disappear, and the rice does not grow. That is, violating adat means violating human life, the result is not only felt by the concerned, but also by all members of the community (Wahid, 2015:96).

\section{Novel}

A novel, according to Sumardjo \& Saini (1988: 29) is a concept of the structure contained in the mind. The novel is a prose-shaped story that has a wide scope. The coverage is because the concept of the story is built by elements of the composition consisting of complex plots, a lot of characters, themes that develop in complex stories, atmosphere and conditions of the various narratives, and the background in the various narratives as well. Meanwhile, based on Suharto's (2002: 43) view, novels are formed by structures that produce meaning. Novels are not a series of writings that describe events that interest people to read them, but are structured by the minds that refer to all existing elements.

The novel is an essay of prose that attempts to tell an interesting (remarkable) event departing from the lives of the characters of the story. The extraordinary events or events contained in the story are born of a conflict and a dispute, which can change their fate (Jassin, 1963:64-65).

\section{METHODOLOGY}

This research uses content analysis method with a qualitative approach. Emzir (2014: 283-285) states that qualitative is a qualitative-oriented procedure of textual interpretation in order to obtain a comprehensive under- 
standing of the issues studied. Then, Titscher, et al. in Ibrahim (2009: 106) explains that content analysis is a method of analyzing text by constructing categories of textual meaning with reference to hidden content and context reconstruction as well as considering the meaning of specific examples.

The data in this study is data about the value of courage of Buginese-Makassarese men in the novel Pulau by Aspar Paturusi. The data are obtained through textual quotations and language exposes in the form of paragraphs, phrases, sentences, and words containing ideas that support the acquisition of deep knowledge about the values of the Buginese-Makassarese women in the novel Pulau by Aspar Paturusi based on Adat point of view through story structure. Furthermore, additional data in the form of excerpts of the notes obtained from understanding the perspective of the Buginese-Makassarese women's values in the novel based on the Adat perspectives that occurred in the Buginese-Makassarese society in the $70 \mathrm{~s}$ era, as well as various reviews that talk about the author' biography, author's life background or directly from the author's own narrative through interviews. Sources of data in this study are the novel Pulau by Aspar Paturusi published by PT Bhakti Ujung Pandang Baru in 1976. In addition, other data sources are from Aspar Paturusi as the author of the novel Pulau.

\section{FINDINGS AND DISCUSSION}

Based on the depiction of the characters involved in the novel Pulau by Aspar Paturusi, it can be seen how the position of the Buginese-Makassarese women in the Adat view. In the reality of life, the role of women is very important, either as a wife, mother, or child. The success of the Buginese-Makassarese men cannot be separated from the support of children and their wives in all activities. Therefore, the Buginese-Makassarese women have some values that are the basic character of the Buginese-Makassarese women who are inherited from their ancestors (to riolo) in maintaining their glory and self-esteem based on Adat (adeq/adaq). Adat should always be upheld and led in the life of society because it teaches the truth or good attitude and behaves and contains rules that work to organize individuals and groups of individuals in interacting with fellow human beings, nature, and God.

\section{Values of Glory}

In the life of the Buginese-Makassarese people, known as the term malebbi'/kalabbirang (glory) is interpreted as a measure of the degree of glory of a person or family. The girls are educated in the middle of a religious family, possessing the ingenuity that impresses itself as a noble (malebbi ') woman. The value of this glory is also greatly guarded by each individual or a social group within the Buginese-Makassarese community. A girl who does not take care of her glory and honor, her social sanction: is positioned in the lowest social class (gau-gau ata). More roughly, synonymous with animals (Buginese-Makassarese: kolo'kolo') that is why Buginese-Makassarese people are putting forward the honor of women. In fact, in relation to the opposite sex, customarily, women's space is strictly restricted. Aminah is a representative of the young woman (virgin) of the Buginese-Makassarese who is described as having noble character (makkunrai malebbi'). The condition is seen in the cleverness that is owned by Aminah in singing the traditional poetries (Pantun), reading Qoran (obedient religion), and weaving. The value of intelligence (Buginese-Makassarese: Amaccang) that she has led herself to be able to choose which one is good and which one is bad.

Ketika Aminah mengucapkan "BATTI-BATTI", ---pantun percintaan yang penuh kiasan, hanya Sattu yang melayaninya. Seorang gadis yang menguasai "batti-batti" yang diucapkan dengan cepat dan diciptakan saat itu juga, biasanya melayani tujuh sampai delapan orang lelaki muda yang akan mundur satu demi satu lantaran kehabisan kata ungkapan. (Data 24/Novel Pulau, Aspar Paturusi: 46)

...Dan Aminah selalu tampil menggemakan "Al Quran" pada tiap perayaan atau pesta keluarga dan sahabat. (Data 25/Novel Pulau, Aspar Paturusi: 35)

When Aminah pronounces "BATTI-BATTI", --- a fantasy pantun, only Sattu serves it. A girl who controls the "batti-batti" is spoken quickly and created on the spot, usually serving seven to eight young men who will retreat one after the other because the word is out of expression. (Data 24 / Novel Pulau, Aspar Paturusi: 46)... and Aminah always appear to echo the "Al Quran" at every celebration or family and friend party. (Data 25 / Novel Pulau, Aspar Paturusi: 35)

\section{Values of Obedience}

The obedience values of the Buginese-Makassarese women are described in the internal relationships of the Sanneng Karang and Salasa Bora families, as reflections of the Buginese-Makassarese women in Adat views. Father (Etta/Tetta) occupies the position of the head of the family and is fully responsible for the survival, safety, and honor of his family. Besides being the head of the household, the father (Etta/Tetta) occupies the function of being the husband and father of his children at once. So is the mother (Amma'/Amma'), she takes on the duties of the wife and mother of her children at once. All have functions and position in a family. In the life of the Buginese-Makassarese society, the position of a father (Etta/Tetta) is feudalistic. His speech is absolute and his direction is a command that must be followed by all family members without exception. There is almost no room for compromise or different opinions, ranging from work to his son or daughter's matchmaking decision. From the perspective of a father (Etta/Tetta), the wife serves as a representative and not a partner in caring for, guiding, and growing their children up. This implies that the wife plays a role in decision-making, educating, living, and governing in the family when the husband or father (Etta/Tetta) is not at home for a relatively long time. When the father 
(Etta/Tetta) is at home, the father (Etta/Tetta) takes back full control of the household responsibility. All of this has been mandated in Adat rules (ade'/ada'). This denial of function and position in this household is considered ungodly (mabusung/bassung).

The obedience of daughters to their father (tetta) and wives to their husbands is a manifestation of the understanding that the Buginese-Makassarese women have of their position in the Panggaderrang (adat) family. Collaboration between religion and Adat becomes a unified whole that is complementary in guiding each family member to run its role and function in order to create a harmonious family. The sense of responsibility as head of the family makes it absolute. Parents raise and educate their children, everything that concerns the principles of life. Children who are polite and obedient to the parents, who direct it easy to be guided to become a good child. This value of compliance is applicable in the life of the Buginese-Makassarese society. The existing social stratification in the Buginese-Makassarese society requires that the value of obedience applied to human relationships as well, especially on the derivatives of the existing king in the community. The value of obedience is applied in various social relations, the obedience of the servants (ata) to the command of the king, the obedience of the people to the agreed rules set forth in pangngadrang/pangadakkang (rapang), and the obedience of the children to their parents, especially to the head of the household; father (Buginese-Makassarese: Tetta), and obedience in carrying out the commands of God Almighty (religion).

The description of the values of the Buginese-Makassarese society's life view as stated in Adat generally describes the internal relations of the family in the life of the Buginese-Makassarese people in Tanjung Bira in harmony. They have a hold of the life that comes from their former people, proven to create a good and harmonious relationship with the internal family. Such harmonious situations can be created because they are in action, always based on shared values of life philosophy. Parents educate their children so ethical and have good morals because based on the concept of values of the Buginese-Makassarese philosophy of life. The way of life that is contrary to those values will lead to internal conflict within the family that destroys the living order of the household. The importance of understanding the values of the philosophy of life should be a common awareness of all members of the family, in order to establish mutual glory (sipakalebbi/sipakalabbi), mutual love (siamasei/sikamalang), mutual respect (sipaka tau/sipaka tau), mutual giving and receiving sipakatuo/sipakatallasa), and remind each other (sipakainge/sipang ngurangi). All these attitudes are a pillar in establishing harmony in marriage for the creation of harmony and happiness in the family.

\section{Values of Obedience, Loyalty, and Tenancy}

One of the social conditions experienced by women of Buginese-Makassarese in Tanjung Bira village, which is often abandoned by husband and relatives went to sea for quite a long time. Such a situation demands the Buginese-Makassarese women to always keep themselves from any behavior that allows for slander which further becomes the gossips in society. The Buginese-Makassarese women are also portrayed as faithful women waiting for their husbands and relatives to go sailing. In the midst of their waiting, the Buginese-Makassarese women fill the time to do various jobs to meet their needs.

Sejak dulu mereka menjalani hidup seperti itu. Isteri-isteri yang ditinggalkan tahu apa yang harus mereka kerjakan. Mereka menenun sarung., Membuat tali dari sabut kelapa. Dengan dokar atau dengan berjalan kaki puluhan kilo mereka membawa dagangan ke kota. Perempuan di kampung itu mencari kayu bakar dengan menempuh tanah berbukit, menebang dan membelah kayu.... Itulah kebiasaan mereka turun temurun untuk tidak berpangku tangan terhadap alamnya. Dari rahim mereka pulalah terlahir anak laki-laki atau perempuan yang kelak dibesarkan dalam keuletan sikap yang diwarisinya. (Data 40/Novel Pulau, Aspar Paturusi: 12)

They had always lived that way. The abandoned wives know what they should do. They weave sarongs and make rope from coconut husk. With a dog ear or by walking dozens of kilometers they bring merchandise to the city. The women in the village searched for firewood by hilly land, cutting and splitting wood. That is their habit of hereditary to not stand idly by her nature. It is from their wombs that they are born boys or girls who are later raised in the resilience of their inherited attitudes. (Data 40/Novel Pulau, Aspar Paturusi: 12)

Here is a description of the value of loyalty and the tenacity of the Buginese-Makassarese women. They are aware of their position and function in the family's internal relationships and relationships in the social life of the community. In terms of work, the husband and wife in the Buginese-Makassarese society's view, the husband is responsible for the life of his wife and the wife is in charge of assisting in maintaining the survival of his family by doing various jobs that can support the improvement of welfare and peace in the household. The tenacity (diligent nature) and loyalty of the Buginese-Makassarese women in Tanjung Bira is a representation of the attitude of the Buginese-Makassarese women in South Sulawesi in general. A hereditary attitude is inherited from their elderly people so in general, they have the tenancy and awareness of the relationship with the natural surroundings.

The implementation of the Buginese-Makassarese' philosophy of life as a benchmark or activity in all life joint activities, appears to men and women of the Buginese-Makassarese society in placing their respective occupations and responsibilities. They do all that with the spirit of hard work (pakkareso). For men, they work as sailors and sail to some areas with hard work and full responsibility and vigilance in the face of all the challenges they face in the middle of their voyage. So even women, they await the arrival of their relatives who go to sea while doing various jobs that have become their responsibility. Narrated in the novel Pulau by As- 
par Paturusi, that when left by relatives go to sea, the women in Tanjung Bira fill the waiting period by doing various activities that have become their routine, among others; weaving sarongs, making ropes from coconut husk, walking dozens of kilometers to bring merchandise to the city, cutting and splitting firewood, and planting corn and digging wells or graves. It has become a tradition of heredity that keeps them idle in their waiting periods. The situation is a picture of the tenacity and perseverance of the Buginese-Makassarese women.

Based on the series of events above, Aspar Paturusi as the author emphasizes the loyalty and tenacity of the Buginese-Makassarese women in the social life of the Buginese-Makassarese community. Aspar Paturusi gives his views on the Buginese-Makassarese women, occupying the crown position in the family that men should protect. However, it does not mean that the Buginese-Makassarese women are seen as weak and cannot do anything. In fact, men are very assisted by the Buginese-Makassarese women who are tenacious in living their daily lives.

Aspar Paturusi describes the Buginese-Makassarese women in actual life reality, happening in the Buginese-Makassarese society life in Tanjung Bira. He actually displays values that must be owned by women. This is indirect, he provides views as a comparison and not as a form of wrong or right. in fact women, in addition to excel in care for themselves, their children and husbands, are also required to engage in efforts to achieve family welfare.

\section{Values of Family Honor}

Novel Pulau by Aspar Paturusi also provides a glimpse of the psycho-social condition of the Buginese-Makassarese community in Tanjung Bira related to the custom of women wearing their pride accessories whenever there is a celebration. It is used as one way or media in maintaining the value of family honor. See the following data:

Sebagaimana perempuan lain, ibunya dan Isah memakai semua perhiasan yang ada. Rupiah dan ringgit emas berkilauan di rumah pengantin hari itu. Selain untuk induk kalung, ringgit emas yang bersusun tiga sampai lima menjadi pernat-pernit kebaya. Dan lima sampai delapan ringgit bersusun jadi gelang yang menghiasi tangan perempuan di desa Bira itu. Pesta serupa itu akan menampilkan simpanan "kebanggaan" mereka. (Data ${ }^{186 / N o v e l ~ P u l a u, ~ A s p a r ~ P a t u r u s i: ~ 11) ~}$

Like other women, her mother and Isah used all the jewelry. Rupiah and gold ringgit sparkled in the bridal house that day. In addition to the parent necklace, gold ringgit stacked three to five to be kebaya decoration. And five to eight ringgit stacked into a bracelet that adorned the woman's hand in Bira village. A similar party will display their "pride" store. (Data ${ }^{186} /$ Novel Pulau, Aspar Paturusi: 11)

The custom of women in the village of Bira as mentioned above, in the view of the Buginese-Makassarese society, is considered as something that can not be ignored. Because according to them, attending a party or celebration becomes a must for women to show the characteristics of existence (asugireng/kakalumnyangang) which shows the degree of the family in the community. On the contrary, the women who are present and do not wear their pride, any worth, as well as dropping the family in the eyes of the people. This is a taboo for them, because the essence of the habit of displaying the decorations, bracelets, etc. in the ringgit value among the Buginese- Makassarese women does not contain the meaning of showing off, but has the meaning that she is not in the poor (tau peddi/to kasiyasi). According to them, displaying the stash of pride is a fairness. Things that are not fair, even a taboo/ban in the message (paseng/pasang) is displaying poverty (tau peddi/to kasiyasi) in the community. Aja mupacomparengngi apeddiremmu lao ri diammu rupa tau (do not show your poverty to your neighbor); Pailloi cappa lipamu na mu ripakalebbi pole ripadammu rupatau (Make the edge of your sarong glow, so that you are appreciated by your neighbor), both sentences containing the message (insert/pairs) This asserts that the Buginese-Makassarese women's habits display jewelry essentially does not contain the meaning of showing off, but nothing more than just declaring wealth (asugireng/ kakalumanyangang) as a value of the philosophy of life that they must have in order to safeguard family honor.

\section{CONCLUSION}

For the customary views passed down by the ancestors of the Buginese tribe (to riolo), the Buginese-Makassarese woman is a symbol of family honor which is associated with a guarded and protected crown. Therefore, Buginese-Makassarese women in social life are always guarding the glory (malebbi/akkalebbireng) by maintaining the dignity of herself, her family, and her group from deviant deeds. In addition, Buginese-Makassarese women always keep themselves from the nature of sins (mabusung), against the father and husband by serving it with sincere feelings without any argument. One of the most distinctive characteristics of the Buginese-Makassarese women is its loyal and tenacious nature. With her loyalty awaits her husband's return from her cruise and overseas. In filling the wait, the Buginese-Makassarese women spend their time working to help their husbands financially and educate their children. In addition, the Buginese-Makassarese women are very firm in guarding her husband's property. Psycho-social habits of the Buginese-Makassarese women have a view that displays the husband's property (asugireng/kakalumnyangang) which shows the degree of the family in the community. On the contrary, the women who were present and did not wear their pride, whatever it was worth, as well as dropping the family in the eyes of the people. The role and function of the family are very dominant in shaping the character of the Buginese-Makassarese women so that the values that are the nature of nature can be applied well in the life of society.

\section{REFERENCES}

Emzir. (2014). Metodologi Penelitian Kualitatif Analisis Data. Jakarta: Rajagrafindo Persada.

Goldmann, L. (1981). Method in the Sociology of Literature. Oxford: Basil Blackrvell. 
Hamid, A., Mattulada, Lopa, B., Abidin, Z., \& Salpmbe C. (2014). Siri' Filosofi Suku Bugis, Makassar, Toraja, Mandar. Makassar: Arus Timur.

Ibrahim, A.S. (2009). Metode Analisis Teks \& Wacana. Yogyakarta: Pustaka Pelajar.

Idrus, N.I. (2014). "Siri', Gender, and Sexuality among the Bugis in South Sulawesi" http://journal.ui.ac.id/index. php/jai/article/download/3527/2803.

Iswary, E. (2010). Perempuan Makassar; Relasi Gender dalam Folklor. Yogyakarta: Ombak.

Jassin. H.B. (1963). Pujangga Baru Prosa dan Puisi. Jakarta: Gunung Agung.
Mattulada, H.A. (2015). Latoa; Antropologi Politik Orang Bugis. Yogyakarta: Ombak.

Rahim, R. (1985). Nilai-Nilai Utama Kebudayaan Bugis. Ujung Pandang: Hasanuddin University Press.

Suharto, S. (2002). Kritik Sastra Feminis; Teori dan Aplikasinya. Yogyakarta: Pustaka Pelajar.

Sumardjo, J. \& Saini, K.M. (1988). Apresiasi Kesusastraan. Jakarta: PT Gramedia.

Paturusi, A. (1976). Pulau. Ujung Pandang: Bhakti Baru

Wahid, S. (2015). Kearifan Adat Istiadat Makassar. Makassar: Arus Timur. 